2021, Volume 16, ATEE 2020 - Winter Conference. Teacher Education for Promoting WellBeing in School. Suceava, 2020, pages: 27-38/ https://doi.org/10.18662/lumproc/atee2020/02

\section{Methods of Ensuring Continuity in the Healthy Lifestyle Development of Senior Preschoolers and Primary School Children}

\section{Tetiana BABIUK ${ }^{1}$}

${ }^{1}$ Candidate of Pedagogical Sciences, Associate Professor, Head of the Department of Theory and Methods of Preschool Education, KamianetsPodilskyi National Ivan Ohiienko University, Kamianets-Podilskyi, Ukraine tanja17@email.ua
Abstract: The paper studies the criteria, indicators and levels of valueconscious attitude to health as an integral indicator of developing bealthy lifestyle of preschool and primary school children. It describes the current state of continuity in the bealthy lifestyle education of senior pre-schoolers and primary school children.

The author defined pedagogical conditions of continuity in the development of healthy lifestyle of senior pre-schoolers and primary school children, developed and implemented into practice methods to ensure continuity in the bealthy lifestyle education in kindergartens and elementary schools, and experimentally tested their efficiency.

Keywords: health, bealthy lifestyle, development of a bealthy lifestyle of preschoolers and schoolchildren, continuity in the healthy lifestyle education of senior preschoolers and primary school children, value attitude towards health, methods to ensure continuity in the bealthy lifestyle education of senior preschoolers and primary school children

How to cite: Babiuk, T. (2021). Methods of Ensuring Continuity in the Healthy Lifestyle Development of Senior Preschoolers and Primary School Children. In O. Clipa (vol. ed.), Lumen Proceedings: Vol. 16. ATEE 2020 - Winter Conference. Teacher Education for Promoting Well-Being in School. Suceava, 2020 (pp. 27-38). Iasi, Romania: LUMEN Publishing House. https://doi.org/10.18662/lumproc/atee2020/02 


\section{Introduction}

The priority of the education system is to foster a responsible attitude to one's own health and the health of others as the highest individual and social value. That is why it is necessary to create conditions in preschool and general secondary education institutions that would promote the development and maintenance of health, establishment of a healthy lifestyle, harmonization of children's relationships with the environment. Such social order of society requires a systematic and complex approach to the development of a healthy lifestyle of preschoolers and schoolchildren.

\section{Literature review}

These issues are diversely covered in modern Ukrainian science. In particular, the works by Dubogaj (2005), Vilchkovskyi (2018), Denisenko (1998) are devoted to the problem of developing a healthy lifestyle through physical improvement; valeologization of education is covered in the works by Boichenko (2008); development of value orientations for a healthy lifestyle is investigated by Orzhekhovska (2006), Yaremenko et al. (2000). The issues of protection, preservation and strengthening of children's health have been studied in the works of Andriushchenko (2014), Volkova (1993) and others. Topical are the works of Bekh (2006) and Kononko (2008) concerning the formation of a healthy personality of children of senior preschool and primary school age (Clipa \& Campan, 2020).

Currently, the problem of continuity in the education system is also of particular importance. The issue of ensuring continuity is reflected in the research of Borisova (1985), Lysenko and Kyrsta (2010) and other scholars. However, the problem of continuity in developing a healthy lifestyle of senior preschoolers and primary school children has not been the subject of a special study yet.

\section{Design and research methods}

The purpose of our study is to develop and implement methods to ensure continuity in developing a healthy lifestyle of senior preschoolers and primary school children. 


\subsection{Methodology}

The state of health of the younger generation highlights the need to develop a healthy lifestyle of children from preschool age. The way of life reflects the type of life of people which is formed under the influence of both objective conditions and internal motivating forces (AbulkhanovaSlavska, 1981). Majority of pedagogical research interpret a healthy lifestyle as a complex set of values and behavioral stereotypes aimed at maintaining and developing health. We have not been able to find in the psychological and pedagogical literature a definition of "healthy lifestyle" that would fully express its essential characteristics. At the same time, an integral interpretation of the phenomenon of a healthy lifestyle is necessary to understand the system of pedagogical work aimed at the development of a healthy lifestyle of children. In this regard, the following definition is formulated: a healthy lifestyle (in the context of its development of children of senior preschool and primary school age) is a complex phenomenon that includes the recognition of health as the highest personal value, desire to be healthy, and practical activities aimed at maintaining health. A versatile understanding of a healthy lifestyle implies that this phenomenon is formed in a specially organized pedagogical activity.

An integrated understanding of a healthy lifestyle implies that this phenomenon can be harmoniously developed in conditions of a specially organized pedagogical activity. According to the content of the concept of "healthy lifestyle" and its structural components (emotional, cognitive and activity-behavioral), as well as components of health (physical, mental, social and spiritual), we have identified indicators of a healthy lifestyle of senior preschool and primary school children.

The emotional and value component involves activity in mastering the skills and abilities of a healthy lifestyle. Indicators: awareness of the value of their own health and the health of others, the presence of interest in selfknowledge, the predominance of internal motives over external, the presence of willful conscious efforts, the ability to assess their own health and the health of others, the desire to master healthy life skills, optimism, self-belief, rejection of the disease. The cognitive component presupposes 
the availability of systemic knowledge about the essence of a healthy lifestyle and its components, the ability to predict the effects of lifestyle on human health. Indicators: knowledge about the vital functions of the main organs and systems of the body, about the factors that affect health, about ways to maintain their health, knowledge about a healthy lifestyle and its components, health and disease, skills to argue the choice of certain techniques and ways of life aimed at maintaining and strengthening health, understanding the importance of a healthy lifestyle for maintaining, strengthening and reproducing health.

The activity-behavioral component involves conscious adherence to the requirements of a healthy lifestyle. Indicators: the presence and observance of healthy lifestyle habits in everyday life, abandonment of bad habits, social activity, empathy, care for their own health and the health of others, compliance with the rules of cultural and health behavior.

The dynamics of development of a healthy lifestyle of children of senior preschool and primary school age is characterized by such criteria of value-conscious attitude to health as an integral indicator of a healthy lifestyle of children of senior preschool and primary school age: knowledge of basics of healthy lifestyle, desire to be healthy, health protecting behavior and activities. Indicators of the criterion "knowledge of the basics of a healthy lifestyle" are knowledge of the structure and functioning of the human body, knowledge of the rules of maintaining health, the ability to justify the choice of ways to maintain health. The indicators of the criterion "the desire to be healthy" are awareness of the value of personal health and the health of others, the presence of interest in personal health. Indicators of the criterion of "healthy behavior and activities" are daily routine skills, the ability to control personal behavior, to communicate kindly with peers, to care for others.

After analyzing the results of the observational experiment, we conditionally divided the subjects into four groups according to the level of development of health values. We determined the levels of health values of senior preschoolers and primary school children and their characteristics in accordance with the defined criteria, namely, knowledge of the basics of a 
healthy lifestyle and activity, independence in mastering the skills of a healthy lifestyle and activities (Table 1).

Table 1. Characteristics of levels of health values development

\begin{tabular}{|c|c|c|}
\hline Levels & Senior preschool age & Primary school age \\
\hline High & $\begin{array}{l}\text { Formed ideas about the structure } \\
\text { and functioning of the main organs } \\
\text { and systems of the human body, } \\
\text { knows the rules of maintaining } \\
\text { their own health and is able to } \\
\text { justify the choice of ways to } \\
\text { maintain health. The child realizes } \\
\text { that his own health and the health } \\
\text { of others is the highest value, is } \\
\text { interested in the state of his own } \\
\text { health. The child adheres to the } \\
\text { daily routine, is able to control their } \\
\text { own behavior, communicates } \\
\text { kindly with peers, and is caring of } \\
\text { the others. }\end{array}$ & $\begin{array}{l}\text { The child has formed knowledge about } \\
\text { the structure and functioning of the main } \\
\text { organs and systems of the human body, } \\
\text { knows the rules of maintaining their own } \\
\text { health and is able to justify the choice of } \\
\text { ways to maintain health, gives real-life } \\
\text { examples, knows the means of natural } \\
\text { healing. The child realizes that his own } \\
\text { health and the health of others is the } \\
\text { highest value, is interested in the state of } \\
\text { their own health. The child willingly } \\
\text { adheres to the daily routine, is able to } \\
\text { control their own behavior, kindly } \\
\text { communicates with peers, and cares } \\
\text { about others without any reminders. }\end{array}$ \\
\hline Sufficient & $\begin{array}{l}\text { The child knows the names of } \\
\text { organs and systems of the body, } \\
\text { indicates their functions, in general } \\
\text { knows the rules and means of } \\
\text { maintaining health, can give } \\
\text { arguments of the choice of some } \\
\text { ways to maintain health. The child } \\
\text { realizes that their own health and } \\
\text { the health of others is a value, and } \\
\text { is interested in the state of their } \\
\text { own health. The child tries to } \\
\text { adhere to the daily routine and } \\
\text { control their own behavior, kindly } \\
\text { communicates with peers, and } \\
\text { shows concern for others. }\end{array}$ & $\begin{array}{l}\text { The child knows the structure and the } \\
\text { way the body functions, can indicate the } \\
\text { functions of organs, knows the rules and } \\
\text { means of maintaining health, is ready to } \\
\text { comment on the choice of ways to } \\
\text { maintain health. The child realizes that } \\
\text { their own health and the health of others } \\
\text { is a value, is interested in the state of } \\
\text { their own health. The child tries without } \\
\text { adherence to follow the routine of the } \\
\text { day and control their own behavior, } \\
\text { kindly communicates with peers, and } \\
\text { shows concern for others. }\end{array}$ \\
\hline Average & $\begin{array}{l}\text { The child can name individual } \\
\text { organs and systems of the body, } \\
\text { has a basic idea of their function, } \\
\text { shows situational awareness of the } \\
\text { rules and means of maintaining } \\
\text { health, but cannot explain the } \\
\text { choice of ways to maintain health. } \\
\text { The child does not think about the } \\
\text { value of their own health and the }\end{array}$ & $\begin{array}{l}\text { The child knows the organs and systems } \\
\text { of the body, has a basic knowledge of } \\
\text { their function, shows situational } \\
\text { knowledge of the rules and means of } \\
\text { maintaining health, not always can justify } \\
\text { the choice of ways to maintain health, or } \\
\text { cannot offer the way of maintaining } \\
\text { health in a particular situation. The child } \\
\text { does not think about the value of h their }\end{array}$ \\
\hline
\end{tabular}




\begin{tabular}{|c|c|c|}
\hline & $\begin{array}{l}\text { health of others, is not interested in } \\
\text { the state of their own health. } \\
\text { Whenever possible tries to avoid } \\
\text { sanative procedures and adherence } \\
\text { to daily routine, selectively } \\
\text { communicates with peers, shows } \\
\text { concern for others. }\end{array}$ & $\begin{array}{l}\text { own health and the health of others, } \\
\text { shows situational interest in the state of } \\
\text { their own health. Knows, but avoids } \\
\text { health procedures, irrationally plans daily } \\
\text { routine, selectively communicates with } \\
\text { peers, shows concern for significant } \\
\text { people. }\end{array}$ \\
\hline Low & $\begin{array}{l}\text { The child's knowledge about the } \\
\text { organs and systems of the body is } \\
\text { limited only by listing separate } \\
\text { organs of the body, without } \\
\text { defining their functions; the child } \\
\text { has almost no idea of how to stay } \\
\text { healthy, does not consider health a } \\
\text { value, avoids health improving } \\
\text { procedures. While among peers, the } \\
\text { child is closed, insecure, avoids } \\
\text { communication or provokes } \\
\text { conflicts. }\end{array}$ & $\begin{array}{l}\text { The child of this level does not know the } \\
\text { structure of organs and systems of the } \\
\text { body, does not determine their functions; } \\
\text { has almost no idea of how to stay } \\
\text { healthy. The child does not consider } \\
\text { health a value, almost does not notice the } \\
\text { health condition of peers and relatives, is } \\
\text { unable to assess their own condition. A } \\
\text { child of this level avoids communication } \\
\text { with peers and adults. }\end{array}$ \\
\hline
\end{tabular}

\section{Source: Author's own contribution}

The conducted observational experiment showed that preschoolers and first-graders have a certain amount of spontaneous, non-systematized knowledge on health issues, try to understand the essence of health activities, they are interested in information about themselves, their body, but the vast majority of children develop this knowledge at the middle level. This fact indicates lack of expansion and deepening of knowledge, skills and abilities aimed at maintaining and improving health conditions. The results of the observational stage of the experiment prove the need for a purposeful approach to the organization of activities aimed at teaching health values.

Improving the effectiveness of the development of a healthy lifestyle of children of senior preschool and primary school age is possible provided that continuity in the work of preschool and primary school is ensured. Its essence is manifested in the connection of the content of educational material, leadership methods and forms of educational process organization, which, on the one hand, aim at preparing children for school, on the other at making optimal use of their preschool health protecting experience. We consider continuity in the development of a healthy lifestyle of senior preschoolers and primary school children as a relationship in the content, 
methods, tools and forms of work with children of senior preschool and primary school age, which provides consistently organized development of a healthy lifestyle through reliance on the achieved level of education and prepares children to meet more complex content requirements in the subsequent stages of training and education.

\section{Research results - statistical data and their interpretation}

The main task of the formative stage of the experiment was the development and implementation of methods to ensure continuity in the development of a healthy lifestyle of senior preschoolers and primary school children. According to the results of the observation stage of the experiment, it is defined those favorable pedagogical conditions for the implementation of this technique are:

1) preparation of teachers for developing a healthy lifestyle of children.

2) cooperation of teachers and parents in the preservation and promotion of children's health.

In order to prepare educators and teachers for the development of a healthy lifestyle of children of senior preschool and primary school age, various forms of methodical work were planned and carried out in a certain sequence: methodological session ("Continuity in developing healthy lifestyles of senior preschoolers and primary school children”); lectures (for example, "Methods of developing a healthy lifestyle of children"), seminars (for example, "Development of a positive attitude to health"), individual consultations and conversations. These actions contributed to the mastery of the conceptual apparatus of health and healthy lifestyles by teachers, awareness of conditions for maintaining and strengthening health based on health values, theoretical foundations of continuity in the educational process. Emphasis was made on further self-education of teachers participants in the experimental study.

Particular attention was paid to the cooperation of teachers and parents on maintaining and promoting children's health. At parents' meetings they received information on the development of a healthy lifestyle (for example, "Health as a universal value"), participated in consultations, 
conversations, classes, reading the contents of folders, which gave advice to parents on various issues of developing a healthy lifestyle of children (for example, "If a child has a cold...", "How to make a child's diet healthy"). Work with parents helped to increase their awareness and activity in children's health protection. Joint classes and lessons, health days, theatrical holidays, quizzes, competitions were dedicated to the involvement of parents in cooperation on preserving and strengthening children's health.

The introduction of methods of ensuring continuity in developing a healthy lifestyle of senior preschoolers and primary school children was aimed at giving children the knowledge about functioning of the human body, conscious choice of ways to maintain health; it increased interest in the study of their own health and ways of health protection, improved the skills of observing daily routine, ability to control their own behavior, communicate with peers and show care for others.

Taking the above mentioned into consideration, the information on healthy lifestyles provided to primary school children was more saturated, detailed, differentiated. It has been proved that in-depth information about the rules of first aid, healthy diet of a first grader at school, computer addiction, and bad habits is necessary for young schoolchildren. It is important for children of this age to revise the material about mental health (how a good mood affects a person's health), social health (how to find friends in a new team). The method of ensuring continuity in developing a healthy lifestyle of senior preschoolers and primary school children took into account peculiarities of the mental development of children of these age groups (visual thinking, leading activities). For senior preschool children, preference was given to the following methods and forms: visual (observation of health conditions during the day, viewing of paintings, illustrations, diagrams, models), practical methods (showing how to perform health actions, exercises, experiments, solving practical problems, having walks and excursions), verbal (stories, reading fiction for children, verbal and logical tasks). Consolidation of ideas of senior preschoolers about a healthy lifestyle was carried out mainly during games ("Neznaiko came to us", "Compose a man", "Repeat the action"). 
In choosing the content and methods of working with younger pupils, we were guided by the importance at this age of verbal reasoning, sensory perception and practical activities. In this regard, preference was given to brainstorming, problem-solving conversations, drawing up health rules, performing individual and group tasks, picking stories from the lives of people who follow a healthy lifestyle. Particular attention was paid to independent observation, educational and game methods (creative tasks, didactic games, crossword puzzles, riddles).

Ensuring continuity in developing of a healthy lifestyle of senior preschoolers and primary school children was manifested in the repetition of the appropriate form of work or its complication. We gradually moved to forms of work that encouraged primary school children to express subjectivity, independence in judgment and creativity. As for extracurricular activities, children were involved in quizzes, playing role games with the participation of senior preschoolers ("Visit to the doctor", "Show care"), making newspapers "In the circle of friends" and "Medicinal plants", viewing and discussing thematic videos.

On the basis of control section, it was found that the introduction of the method of ensuring continuity in developing a healthy lifestyle of senior preschoolers and primary school children has led to significant changes in the levels of developing value-conscious attitude to health of children of this age (Table 2; 3).

Table 2. Quantitative distribution of children by level of education values of health (older preschool children)

\begin{tabular}{|c|c|c|c|c|c|c|c|c|c|c|}
\hline \multirow{3}{*}{ Levels } & \multicolumn{4}{|c|}{$\begin{array}{l}\text { Experimental group } \\
(140 \text { persons })\end{array}$} & \multirow{3}{*}{ 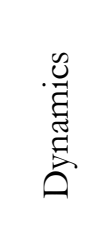 } & \multicolumn{4}{|c|}{$\begin{array}{l}\text { Control group } \\
\text { (130 persons) }\end{array}$} & \multirow{3}{*}{ 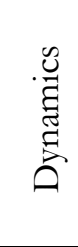 } \\
\hline & \multicolumn{2}{|c|}{$\begin{array}{l}\text { stated } \\
\text { stage }\end{array}$} & \multicolumn{2}{|c|}{$\begin{array}{l}\text { formative } \\
\text { stage }\end{array}$} & & \multicolumn{2}{|c|}{$\begin{array}{l}\text { stated } \\
\text { stage }\end{array}$} & \multicolumn{2}{|c|}{$\begin{array}{l}\text { formative } \\
\text { stage }\end{array}$} & \\
\hline & persons & $\%$ & persons & $\%$ & & persons & $\%$ & persons & $\%$ & \\
\hline High & 26 & 18,6 & 50 & 35,7 & $+17,1$ & 23 & 17,7 & 26 & 20,0 & $+2,3$ \\
\hline Sufficient & 14 & 10,0 & 63 & 45,0 & $+35,0$ & 15 & 11,5 & 23 & 17,7 & $+6,2$ \\
\hline Average & 78 & 55,7 & 26 & 18,6 & $-37,1$ & 70 & 53,9 & 71 & 54,6 & $+0,7$ \\
\hline Low & 22 & 15,7 & 1 & 0,7 & $-15,0$ & 22 & 16,9 & 10 & 7,7 & $-9,2$ \\
\hline
\end{tabular}

Source: Author's own contribution 
Table 3. Quantitative distribution of children by level of education values of health (children of primary school age)

\begin{tabular}{|c|c|c|c|c|c|c|c|c|c|c|}
\hline \multirow{3}{*}{ Levels } & \multicolumn{4}{|c|}{$\begin{array}{l}\text { Experimental group } \\
\text { (170 persons) }\end{array}$} & \multirow{3}{*}{ 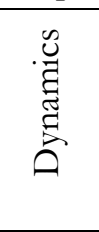 } & \multicolumn{4}{|c|}{$\begin{array}{l}\text { Control group } \\
\text { (180 persons) }\end{array}$} & \multirow{3}{*}{ 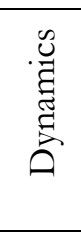 } \\
\hline & \multicolumn{2}{|c|}{$\begin{array}{l}\text { stated } \\
\text { stage }\end{array}$} & \multicolumn{2}{|c|}{$\begin{array}{c}\text { formative } \\
\text { stage }\end{array}$} & & \multicolumn{2}{|c|}{$\begin{array}{l}\text { stated } \\
\text { stage }\end{array}$} & \multicolumn{2}{|c|}{$\begin{array}{l}\text { formative } \\
\text { stage }\end{array}$} & \\
\hline & persons & $\%$ & persons & $\%$ & & persons & $\%$ & persons & $\%$ & \\
\hline High & 47 & 27,6 & 98 & 57,7 & $+30,1$ & 35 & 19,4 & 39 & 21,7 & $+2,3$ \\
\hline Sufficient & 30 & 17,7 & 49 & 28,8 & $+11,1$ & 46 & 25,6 & 48 & 26,7 & $+1,1$ \\
\hline Average & 82 & 48,2 & 23 & 13,5 & $-34,7$ & 84 & 46,7 & 81 & 45,0 & $-1,7$ \\
\hline Low & 11 & 6,5 & 0 & 0 & $-6,5$ & 15 & 8,3 & 12 & 6,6 & $-1,7$ \\
\hline
\end{tabular}

Source: Author's own contribution

The data in the tables show the positive dynamics of developing children's health values. As a result of the experimental method, the number of children in the experimental group who have a high level of development of health values increased by $17.1 \%$ (senior preschoolers) and by $30.1 \%$ (primary school children). Positive is a high level of children's health value development in the experimental group, in contrast to children in the control group. Pupils of the control group after working according to the traditional method also had positive changes in the development of health values, but they are insignificant. The results of control sections in the experimental group showed an increase in children's interest in knowledge about the structure and functions of the human body, awareness of the value of health, desire to engage in health activities. Dynamics of positive changes of the pupils of the experimental group allows us to conclude that experimental techniques provided continuity in the development of a healthy lifestyle.

\section{Conclusions}

Summarizing the above mentioned, we can define a healthy lifestyle as a category whose developing is significantly influenced by the child's motivation for a healthy existence, awareness of the value of health, inner readiness to lead a healthy lifestyle and activity and independence in various 
activities aimed at preserving health. Taking into consideration the specifics of life experience of senior preschoolers (Clipa \& Campan, 2020) and primary school children, due attention should be paid to providing them with knowledge about the basics of health, about themselves as human beings, which are best perceived and developed in various types of children's activities: play, communication, art, subject-practical.

The coonducted study does not cover all aspects of solving the problem of continuity in the development of a healthy lifestyle of senior preschoolers and primary school children. Further study is needed on the issues of continuous development of a healthy lifestyle of children at earlier stages of development (younger and middle preschool age); substantiation of ways to ensure continuity in the development of a healthy lifestyle in educational institutions of different types, in different activities of children of senior preschool and primary school age; work with the management of preschools and primary schools in the context of developing a healthy personality of the child.

\section{References}

Abulkhanova-Slavska, K. A. (1981). Razvitiye lichnosti v protsesse ₹̧hiznedeyatelnosti. Psikhologiya formirovaniya i razvitiya lichnosti. Nauka.

Andriushchenko, T. K.(2014). Do zdorovia doshkilnykiv-kompetentnisnyi pidkhid. Doshkilne vykhovannia, 11, 18-21.

Bekh, I. D. (2006). Vykhovannia osobystosti: Skhodzhennia do dukhovnosti. Lybid

Boichenko, T. I. (2008). Zdoroviazberihaiucha kompetentnist yak kliuchova v osviti Ukrainy. Osnoyy zdorovia i fisychna kultura, 11-12, 6-7.

Borisova, Z. N. (1985). Nastupnist u navchalno-vykhovnij roboti dityachogo sadka i shkoli. Rad.shkola

Clipa, O. \& Campan, E. (2020) Social-Emotional competences of Preschoolers: The impact of Outdoor Educational Activities. Peter Lang GmbH. http://doi.org/10.3726/b17440

Denisenko, N. F. (1998). Vprovadzhennya programi z valeologiyi. Doshkilne vykhovannia, 9, 7-8.

Dubogaj, O. D. (2005). Navchannia v rusi. Zdorov'iazberigaiuchi pedagogichni tekhnologiyi v pochatkovij shkoli. Kiev 
Kononko, O. L. (2008). Vykhoviiemo zdorovu osobystist. Materialy Mizhnar. nauk.-prak.t. konf. "Suchasne doshkillia: realii ta perspektyry". Kyiv, NPU imeni M. P. Drahomanova (pp. 16-20).

Lysenko, N. V., Kyrsta, N. R. (2010). i. Kyiv, Vydavnychyi dim “Slovo"

Orzhekhovska, V. M. (2006). Pedahohika zdorovoho sposobu zhyttia. Shliakh osvity, 4, 29-32.

Vilchkovskyi, E. S. (2018). Osnovy zdorovia i fisychna kultura ditei molodshoho shkilnoho viku : metodychni rekomendatsii. Lutsk.

Volkova, S. S. (1993). Azbuka zdorovya v pochatkovij shkoli. I V seukrayinska naukovo-praktichna konferenciya "Zdorovya ta osvita", Lviv. 1, 66-68.

Yaremenko, O., Vakulenko, O., \& Zhalilo, L. (2000). Formuvannya zdorovogo sposobu zhyttya: navch. posibnyk dlya slukhachiv kursiv pidvyshbennya kvalifikaciyi derzhavnykh sluzhbovciv. Ukrayinskyj in-t socialnykh doslidzhen. 